\title{
Current Views on Issues and Technology Development in Forensic Accounting Education of Indonesia
}

Tarjo $^{1, *}$, Zuraidah Mohd Sanusi ${ }^{2}$, Prasetyono ${ }^{1}$, Mohammad Nizarul Alim ${ }^{1}$, Rita Yuliana ${ }^{1}$, Alexander Anggono ${ }^{1}$, Yusarina Mat-Isa ${ }^{3}$, Henryan Vishnu Vidyantha ${ }^{1}$, Mochamad Ali Imron ${ }^{4}$

${ }^{1}$ Universitas Trunojoyo Madura, Bangkalan, 69162, Indonesia

${ }^{2}$ Accounting Research Institute, Universiti Teknologi MARA, Shah Alam, Selangor, 40450, Malaysia

${ }^{3}$ Faculty of Accountancy, Universiti Teknologi MARA, Puncak Alam, Selangor, 40450, Malaysia

${ }^{4}$ Universitas Islam Indonesia, Yogyakarta, 55584, Indonesia

\section{A R T I C LE IN F O}

Article history:

Received: 09 November, 2020

Accepted: 26 December, 2020

Online: 10 January, 2021

Keywords:

Key Forensic Accounting

Key Explanatory sequential mixed

method

Key Forensic Accounting

Education

\begin{abstract}
A B S T R A C T
The objective of this study is to examine the current views of academics on issues and technology development in forensic accounting education. By applying the explanatory sequential mixed method, this study tries to acquire a better understanding of current perception regarding forensic accounting education. This study indicates that demand for forensic accounting services is expected to increase and offered as a separate courses at the graduate and undergraduate levels; respondent's perceived forensic accounting education as being relevant and beneficial to the business community, the accounting profession, and accounting students. Several technology tools and data analytics in investigation and analysis have been identified as important forensic accounting topics for curriculum developments. The limitation of this study is the small sample. A low response rate could be the result of this study containing bias so that it cannot be generalized, and most respondents are from accounting majors. These results are useful for universities in integrating forensic accounting education into their curriculum or redesigning their forensic accounting courses. The study shows the current view on forensic accounting education in Indonesia. Using an explanatory sequential mixed method is considered as a novelty of the present study.
\end{abstract}

\section{Introduction}

Nowadays, skill in forensic accounting becomes a requirement for the auditor to increase the probability of fraud detection [1]. If that so accounting profession need forensic accounting education? Some of the reasons for the importance of forensic accounting education today are because of the mass cases that occurred in the world such as Enron, WorldCom, and others. The other reason is the existence of new standards and changes in standards, beginning with the Sarbanes Oxley Act 2002 and changes to SAS 99. Both of these standards require auditors to detect fraud [2]. Changes in technology are also making forensic accounting more important because in the digital era, fraud not only occurred in financial statements but also cyber-crime, intellectual property (IP) fraud, piracy, forgery, and personal data [3]. When this financial fraud

\footnotetext{
${ }^{*}$ Corresponding Author: Tarjo, Universitas Trunojoyo Madura, Email: tarjo@trunojoyo.ac.id

www.astesj.com
}

https://dx.doi.org/10.25046/aj060109 combines with the use of computer and digital documents, fraud can falsify invoices or electronic money laundering. Consequently, electronic evidence of such crimes is found on personal computers (PCs) and company-owned mainframes, employee personal PCs, corporate networks, PDAs, diskettes, floppy disks, smart cards, and web servers on external networks [4]. Study shows that despite many cases involving fraud in large companies in the 2000 s, only a few universities offer forensic accounting courses [5].

As far we know, there are many corruption cases in Indonesia, for example, Hambalang, a sting operation conducted by the Corruption Eradication Commission against several government officials. Also, in Indonesia, Insurance companies are now required by the Financial Service Authority to have fraud control and implementation anti-fraud strategies. This strategy includes prevention, detection, investigation, reporting, sanction, monitoring, evaluation, and follow-up. In line with the above 
events, previous studies show that the demand for forensic accountant services is on the rise [5-7]. This demand was responded by various universities worldwide to offer programs or forensic accounting courses [5, 7-9]. Likewise, in Indonesia, many universities offer forensic accounting programs to meet high demand [10].

With the increasing number of universities offering forensic accounting education and the importance of knowledge about topics to support accounting students' future careers, this study examines academicians' opinions regarding forensic accounting education. These results can help academicians in developing or enhancing their curriculum choices in this field, helping students who are interested in career choices in choosing programs that can develop valuable expertise for the profession, and underline the importance of an interdisciplinary approach in forensic accounting education. In [11], the author said there are three reasons why should add a forensic curriculum. The first one is to prepare the students for their careers in accounting, the second is to improve the curriculum and the last one is for better employment opportunities. Using a mixed-method approach, this study describes forensic accounting education in Indonesia. It contributes to the forensic accounting curriculum and its results should be of concern to the accounting profession, academicians, and, in particular, to professional accountancy bodies, providing guidance that may influence how they approach or respond to this increasing demand for forensic accounting. This study aims to answer the following questions:

- What are educators' current views on forensic accounting?

- How do educators perceive obstacles in providing forensic accounting education?

- How do educators perceive important topics of forensic accounting?

- How do educators perceive various teaching methods in forensic accounting?

The next part reviews forensic accounting literature. This section discusses the literature review of forensic accounting, followed by a description of the research design to execute the study. Section 4 discusses the findings and results. The last section would be the conclusion and the implication of the findings, Limitation, and suggestion.

\section{Literature Review}

\subsection{Perception of Forensic Accounting Education- Academicians}

In the 2000s financial report scandals and frauds were widely published; hence, Barry Melancon - CEO of the American Institute of Certified Public Accountants - motivate academicians to teach students with "knowledge and skills to comprehend the essential attribute of fraud, identify factors indicating fraud, and obtain interview techniques [12]. The CEO stated that fraud, embezzlement, and other financial crimes that occur in the modern business environment makes the accounting and audit profession must have training and expertise to detect fraud [13]. These facts emphasize the need for courses specifically focusing on forensic accounting, assuming the audit course cannot provide sufficient training in fraud detection [5].
With this demand, it increases awareness of the importance of expertise in forensic accounting that can advance the ability to spot fraud $[2,14]$. The Public Company Accounting Oversight Board (PCAOB) said that detecting fraud is a very important goal in auditing [1]. Research on the importance of forensic accounting education $[5,7-9,15,16]$. These studies also suggest that forensic accounting education has evolved from initially limited to training in professional education for accountants to something currently offered as courses in several universities. Therefore, there is research that develops a guideline to serve the needs of academicians and practitioners, namely (1) to better understand the knowledge and expertise needed in the field of forensic accounting and (2) to assist academicians and professionals in developing appropriate subject matter and programs [15].

In [16], the author indicated that demand for forensic accounting services increases in the future and the Certified Fraud Examiner (CFE) practitioners chose to offer separate forensic accounting courses while academicians tended to integrate forensic accounting courses in accounting and auditing courses. Also, both groups stated that the accounting curriculum is not sufficient enough to fulfill the demand for forensic education and future accounting curriculum should add accounting forensic education. Their research also concluded that there were differences in perceptions between practitioners and academicians regarding the topics of forensic accounting. The most significant difference between both respondents is on the following topics: professional interview skills and legal aspects of interviews; and professional standards on forensic accounting. Both of the respondents believe that forensic accounting education has several benefits one of which is meeting the requirements for new regulations. However, several impediments like lack of faculty interest, lack of resources, and lack of flexibility in curriculum content mentioned as an obstacle in teaching the topic of forensic accounting by academics.

While the research of [7] signified the same thing that demand for forensic accounting services would increase in the future. Respondents prefer to integrate forensic accounting in accounting and audit courses. This is due to the challenges in terms of regulations, economics, social, ethics, and law faced by corporate that encourage an increase in demand for forensic accounting to create an accounting program to focus more on this field. As for learning techniques, the most important respondents choose from cases and books. The results of this study describe that there are different opinions between practitioners and academicians over 18 of the 49 subjects offered. But both of the respondents say that the majority of these topics are considered important. This study suggests that the topics offered in forensic accounting can be classified into three main sections in the forensic accounting module. the three main groups can be arranged as follows: the first part about basic fraud (such as types of fraud, fraud prevention, and deterrence programs and financial statement fraud), the second is related to corporate governance and legal aspects (earnings management, financial reporting process and analysis, white-collar and economic crimes, and criminology) and the latter focuses on topics related to careers in forensic accounting (expert 
Tarjo et al. / Advances in Science, Technology and Engineering Systems Journal Vol. 6, No. 1, 78-86 (2021)

testimony and expert witness techniques, litigation consulting techniques). Meanwhile, the main setbacks to integrate forensic accounting into the accounting or auditing curriculum are the lack of financial resources, instructional materials, administrative support, and faculty interest.

In [5], the author studied survey academicians and practitioners regarding forensic accounting education. The results of his research showed that respondents preferred to offer forensic accounting in different subjects at the graduate or postgraduate level. Practitioners and academicians also have different perceptions about the topics taught and choose experiential learning as the most important learning techniques. Both of these professions agree that it is very important to teach forensic accounting courses in the accounting curriculum because this field experienced tremendous growth and the enormous interest of students. This research also shows that forensic accounting expertise will be very useful even though students do not take careers in forensic accounting. Respondents of this study also revealed that the lack of resources and the lack of qualified lecturers in teaching forensic accounting such as teaching topics on litigation, teachers must understand and have carried out this litigation process so that they do not only understand theoretical issues.

There is research on curriculum models and guidelines related to important topics that should be included in a forensic accounting course to meet the needs of students and companies [17]. In December 2003, a project funded by a grant from the National Institute of Justice at the West Virginia University Accounting Division was given to develop educational guidelines for academics, instructors, and students interested in fraud and forensic accounting. This project was implemented by forming a planning panel and Technical Working Group (TWG) that have expertise in this field. The results of the two-year project were curriculum models for fraud education and forensic accounting based on collaborative thinking among researchers, professional practitioners, and academicians to develop guidelines designed to help academics, universities, professors, course developers, and professionals. This TWG shows that the following main topics that must exist in the fraud and forensic accounting curriculum are criminology, fraud prevention, deterrence, detection, investigation, and remediation Forensic and litigation advisory services, including research and analysis, valuation of losses and damages, dispute investigation, and conflict resolution (including arbitration and mediation). This research can help universities, instructors, curriculum makers, and professional training to provide appropriate curriculum and topics in the field of forensic accounting, provide students with an initial understanding of fraud or forensic accounting, as material for reviewing audit courses, accounting so that the following forensic accounting practices. It also provides curriculum recommendations and course guides that can be used by users and finally provides training and development in the fields of fraud and forensic accounting for its users.

Research in [18], conducted a survey on CFE found several forensic accounting skills that were not taught in accounting programs such as interviewing and interrogation skills, sources of evidence, schemes of fraudulent financial reporting, criminology, computer/internet crime techniques, and expertise in human relations. This study shows that for a career in the field of forensic accounting must have technical skills and non-technical skills. Non-technical expertise includes ethics, collecting evidence, evaluation, documentation, and interviews as well as oral and written communication. This research provides suggestions for educators to help students learn both of these skills. Both of these skills are considered important for auditing financial statements properly. So when educators prepare their students with these two skills they can succeed in a career of fraud or forensic accounting.

\subsection{Development of Forensic Accounting Education}

During the period of accounting scandals that received considerable attention from around the world in the 2000s, there were still few forensic accounting educations available. Empirical evidence shows that in the very rapid development of forensic accounting, universities respond slowly to teach this topic to students [19]. In the next study, it was found that 21 universities were offering forensic accounting courses [7]. Then there was research on accounting education literature published in six journals for four years (2006-2009), showing that there is an increase in research related to the topic of fraud and forensic accounting, ethics, and professional responsibility [20]. Those studies recommended the content of forensic accounting embracing behavioral science [21], ethics and legal aspects [22], digital forensics [23], litigation consulting services [24].

Research in 2010 conducted a survey of 171 schools that were certified Association to Advance Collegiate Schools of Business (AACSB) to determine which universities offered forensic accounting and fraud checks [25]. The results indicated that only 4 of 171 schools offered degree programs for forensic accounting. While from 171, only 20 universities offered one forensic accounting course, and only 27 offered at least one fraud examination course. The research also shows that seven universities offer both forensic accounting courses and fraud checks.

In 2014, research was conducted on more than a thousand universities around the world, offering accounting programs to determine the extent to which forensic accounting education was taught [9]. Particularly, this survey involved 900 universities in the US and 186 universities in other countries. The study determined that 447 universities surveyed offered separate forensic accounting courses. Additionally, the study also found that 187 of the 1086 schools surveyed offered undergraduate and graduate special forensic accounting degrees, concentration, or specialization. Of course, the findings were a remarkable increase from previous research [25]. This study stated that this is strong and positive momentum in the development of forensic accounting education.

From previous studies, we know that forensic accounting education is developing rapidly throughout the world. The 
demand for forensic accounting education is quite high. This is indicated by the number of universities that have begun providing forensic accounting courses. The availability of forensic accounting education is expected to be able to answer the challenges that the auditors today are expected to be more aggressive in finding fraud that occurs. Nowadays finding fraud is a must in the accounting profession. With the growing complexity of the business world, the development of technological challenges in finding and preventing fraud will be increasingly difficult. Forensic accounting expertise will be increasingly needed. Research shows that demand for forensic accounting services will increase in the future $[5,6]$.

Research by [26] provides an overview of forensic accounting in the United Kingdom. Using questionnaires and in-depth interview methods try to explore perceptions of forensic accounting, profiles of people who work in this field, services offered, paramount expertise and knowledge needed, practitioners and academics respond to its development, and whether this should be considered a new profession. The results of this study show that accounting forensic is growing rapidly in the UK and its profession is dominated by qualified accountants, but in the last two years besides accountants who have taken part in this profession doubled. Forensic accounting is not a profession, according to this study naturally forensic accounting is a multidisciplinary science and it is very broad and deeper than any other profession that exists. Therefore, this field is too broad for someone to have all the knowledge, expertise, and do everything well.

Recently it shows that forensic accounting education is very important. With the rapid development of education, it is deemed necessary to research current forensic accounting education from an academician's perspective. This study surveyed to determine the latest views on various matters regarding forensic accounting education in academics.

\section{Research Method}

This study applies the Explanatory Sequential Mixed Methods Design [27]. This method includes two phases in which the researcher collects quantitative data in the first stage, analyzes the results, and then uses the results to plan (or built into) the qualitative phase. Quantitative results usually inform the types of the respondent that chosen for the qualitative step and the types of questions to be asked to them. The overall purpose of this design is for qualitative data to help explain in more detail the initial quantitative results.

- The researchers surveyed accounting academicians to answer questions about forensic accounting education sent online. This questionnaire focuses on the perceptions of accounting academicians regarding the development of forensic accounting, problems that become obstacles in the teaching of forensic accounting, important topics that must be taught in forensic accounting courses, and what are the best methods in learning forensic accounting. At the beginning of the questionnaire collects demographic and background information for classification purposes. The validity of the questionnaire using Cronbach's alpha is 0,962. The questionnaire uses five Likert scales from 5 (very important or very agree) to 1 (very insignificant or strongly disagree).

- In the second stage, the researcher conducted interviews on the results obtained from the first stage. The results of this questionnaire are the basis of the material used to conduct interviews with respondents. Interviews were conducted with respondents who taught forensic accounting courses. The purpose of this interview is to collect detailed data on the development of forensic accounting, obstacles in teaching forensic accounting, important topics taught in forensic accounting courses, the best methods in the process of learning forensic accounting and the last respondents will be asked about anything they want to add in the curriculum of forensic accounting. Also by conducting interviews we can get a better understanding of the opinions of academics regarding forensic accounting education. Using member checking determines the accuracy or validity at this stage. Member checking is taking the result of a report or themes returned to the informant to test whether the informant feels that they are accurate [27]. Two respondents were selected to conduct interviews. The respondents have experience teaching accounting for more than 10 years. Respondents also have certification in forensic accounting so that they have a good understanding of the field of forensic accounting. Researchers also included responses to forensic accounting education in Indonesia from respondents who filled out questionnaires to further enrich the results of this study. Based on the description above, the model in this study is as follows.
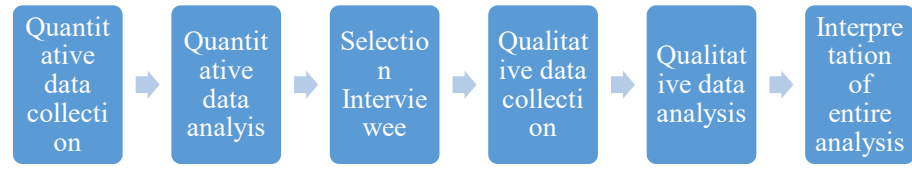

Figure 1: Research Model

\subsection{Research Sample}

A total of 120 accounting lecturers were randomly selected to complete an online survey related to forensic accounting education. The reason for choosing this sample is because those who teach in the accounting department are considered to have an understanding and knowledge of forensic accounting. The response rate is $39 \%$.

\subsection{Data Analysis}

Descriptive statistics are used to analyze the results collected through the interview stage. This data is processed using IBM SPSS 24.0. In the qualitative stage, the coding and thematic analysis are carried out by the Qualitative Software and Research (QSR) 12 Plus. The qualitative analysis includes (1) preparing transcribing interviews and writing memos; (2) start the coding 
process; (3) developing themes based on code (4) Interrelating themes; (5) interpretation of themes [27].

\section{Discussion and Analysis}

The survey showed that the data processed was 47 , which characteristics demographics of the respondents indicated that 25 were male and 22 were female with an average age of 42 years. The majority of the respondent's education level is educated master, which is 30 people or $64 \%$. Then there is an educated Doctor level which is 17 people or $36 \%$. While respondents who had certification in the forensic field (Certified Fraud Examiner and Certified Forensic Auditor) were 19\%.

\subsection{Development of Forensic Accounting}

The findings of this study indicate that forensic accounting services will increase in the future both in terms of litigation support, expert information, and fraud examination. Requests for litigation support and expert witness increased by $89 \%$, while $11 \%$ of respondents answered remained. Fraud examination services as much as $98 \%$ responded to increase while the remaining $2 \%$ answered decreasing. Other research results also show that the majority of these three services are increasing [5-7]. According to research [26], the expert witness has become an important service in the UK, even this service is at the top of the forensic accounting services. As we know that forensic accounting is developing very rapidly and this is followed by forensic accounting services that will continue to increase in the future. According to the informant on the development of forensic accounting:

"Services in this field have the potential to develop and forensic accounting competencies are needed, especially in finance and the public sector"

This statement confirms that the role of forensic accounting is important in finance and the public sector. Indonesia has many cases of corruption in the public sector, of course, competence in the field of forensic accounting can provide great added value to achieve good governance and in the prevention, detection, and investigation of fraud. However, forensic accounting services are very broad-ranging from business valuations to property cases in divorce [26]. The research of [26] also states that there are twelve services in forensic accounting. This means that forensic accounting has good prospects and opportunities to be developed in the future. But does not rule out the possibility of further forensic accounting services will continue to grow.

In academics itself, the development of forensic accounting also continues to occur. Respondents mentioned that at the university where she taught:

"The curriculum offered also continues to change. We invite an expert to advice on the forensic accounting curriculum".

This development is certainly very encouraging and forensic accounting has now penetrated other aspects such as social, www.astesi.com technological, psychological aspects, etc. With the development of technology, of course, there will always be continuous improvement in forensic accounting. Where a system will always be looked for weaknesses and as soon as that too there must be prevention and detection of acts of fraud that occur. Respondents said, "This is like a race between a thief and the police".

Next, the respondents were asked their opinion on how to integrate forensic accounting education in the curriculum. Table 1 shows that the majority of respondents (68\%) chose to offer the topic of forensic accounting separately, as many as $30 \%$ chose to integrate it into accounting and audit courses while the rest chose not to offer (2\%). Additionally, respondents were also asked for their opinion on whether forensic accounting education was offered at the level of Bachelor, Master, or both (Bachelor and Master education. Table 1 also shows that most respondents answered that forensic accounting education must be taught at both Bachelor's and Master's levels. While those who choose are taught at the Master level as much as $45 \%$, the remaining $6 \%$ choose at the Bachelor level only.

Table 1: Perception of How Forensic Accounting Should Be Integrated and What Preferred Level

\begin{tabular}{llll}
\hline $\begin{array}{l}\text { Integrated into } \\
\text { Curriculum }\end{array}$ & Response (\%) & Preferred level & Response (\%) \\
\hline $\begin{array}{l}\text { Integrate } \\
\text { throughout the }\end{array}$ & $14(30 \%)$ & Bachelor & $3(6 \%)$ \\
$\begin{array}{l}\text { accounting and } \\
\text { audit course }\end{array}$ & & & \\
$\begin{array}{l}\text { Offered separate } \\
\text { course }\end{array}$ & $32(68 \%)$ & Master & $21(45 \%)$ \\
$\begin{array}{l}\text { Do Not Cover } \\
\text { Forensic }\end{array}$ & $1(2 \%)$ & Bachelor and & $23(49 \%)$ \\
Accounting at all & & Master & \\
\hline
\end{tabular}

This result is conforming to the study of Kramer et al.'s (2017) which indicates that forensic accounting education is offered separately at the undergraduate and postgraduate educational levels. This result is different from research $[7,16]$. In their research, it was stated that forensic accounting is better integrated into accounting and audit courses. This difference can be caused by the development of forensic accounting not only in accounting and auditing but also in multi-disciplines [5]. As we know nowadays the development of forensic accounting covers a variety of disciplines. Not only accounting and auditing, but also law, information technology. Even according to [26] behavioral sciences such as psychology, sociology, criminology, and anthropology can support the field of forensic accounting. The research of [26], who researched in the UK, showed that the forensic accounting profession from non-accounting has more than doubled for IT experts and experts in other fields in the last two years. But now according to respondents who work as lecturers said:

\section{"at the Bachelor level the forensic accounting course is still an introduction, so to become an expert in this field is required the next level of masters and certification".}

This means that formal education is quite important but there must be a need for certification in the field of forensic accounting. 
This is following the current conditions in which forensic accounting has developed into a multi-disciplinary discipline so there is a need for certification that will greatly support this profession. Thus forensic accounting becomes an interesting science to keep on developing. Because as long as there is still fraud it is necessary to know how to detect and prevent this. For this reason, cooperation between various parties in Indonesia is needed to advance forensic accounting. There needs to be collaboration from academics and practitioners to do it. As conducted [17], which invited academics and practitioners in the field of forensic accounting to spend their time, ideas, and views on developing better education and training in fraud and forensic accounting. That way forensic accounting will develop in a better direction because the one who formulates education and training is the competent party in their field. The development of forensic accounting must move in line with the complexity of the case at this time. That way this profession will increasingly attract interest from students to work as forensic accountants.

\subsection{Perception of Obstacles in Providing Forensic Accounting Education}

Lecturers also asked their opinion about obstacles in providing forensic accounting education. Table 2 shows the mean and standard deviations of the responses of the respondents.

Table 2: Obstacles in Forensic Accounting Education

\begin{tabular}{lcc}
\hline \multicolumn{1}{c}{ Obstacles } & Mean & Standard Deviation \\
\hline $\begin{array}{l}\text { Lack of qualified } \\
\text { lecturer }\end{array}$ & 3,9362 & 0,8184 \\
$\begin{array}{l}\text { Lack of administrative } \\
\text { and financial support }\end{array}$ & 3,3617 & 1,1117 \\
$\begin{array}{l}\text { Lack of pedagogical } \\
\text { materials }\end{array}$ & 3,0426 & 0,9771 \\
$\begin{array}{l}\text { Lack of student interest } \\
\text { Lack job job }\end{array}$ & 2,9149 & 1,0179 \\
opportunities fir in & 2,3617 & 0,8451 \\
\begin{tabular}{l} 
Lack of proper fit iccounting \\
\hline
\end{tabular} & 2,2553 & 0,8715 \\
\hline
\end{tabular}

According to the academicians, the main obstacle in forensic accounting is the lack of qualified lecturers, lack of administrative and financial support, and lack of pedagogic forensic accounting, which is indicated by the mean value higher than 3 . The results are conforming to previous studies which mentioned these are the problems in forensic accounting education [5, 7, 16]. One respondent agreed that the obstacle in forensic accounting education was the lack of teachers. The respondent said, "The availability of teachers and practitioners is still limited". Further respondents also said the reasons for this obstacle were:

"Information update, to find out how fraudster does crime, what motivates it, etc. Usually, we always lag because updating is always a challenge for academics. Because teachers focus a lot on teaching, taking care of study programs, etc. Unless the research is focused there are no problems. Because there will always be a lot of reading. So sometimes the updates are only about the topic of teaching academics, even though forensic accounting is very broad in scope"
Based on respondents' opinions, this was due to a lot of works such as teaching and becoming part of faculty management which was quite time-consuming. This is in line with the results of a survey which states that the lack of lecturer competencies is a major obstacle in forensic accounting education. The interview also mentioned that the scope of forensic accounting is very broad, this is following the statement that forensic accounting involves multiple disciplines making it difficult for teachers to follow their development. It takes a lot of reading material and of course, time is also needed. As a result, teachers only follow the development of the courses being taught.

Meanwhile, respondents disagree if a lack of student interest and job opportunities and lack of conformity with accounting are obstacles in forensic accounting education. This can be seen with a mean value of less than 3 . Student interest and job opportunities in this field are very large. Even the research of [5], mentioned that the employment opportunities for forensic accounting are very numerous. Even if students do not choose a career in forensic accounting, the skills learned will make them better professionals whether it works as an auditor, manager, or consultant. If related to research [26], forensic accounting services in the UK are multiplying. This is proof that interest and job opportunities in the field of forensic accounting are very promising. Whereas for the suitability of forensic accounting with accounting is also not a major obstacle, indeed forensic accounting is multi-disciplinary, but the respondents consider that this is still following accounting and lecturers can teach forensic accounting in their department.

\subsection{Important Topics in Forensic Accounting}

Some important topics to be taught in forensic accounting. Whereas [18], in their research said that interviewing and interrogation skills, sources of evidence, schemes of fraudulent financial reporting, criminology, computer/internet crime techniques, and expertise in human relations are not taught in accounting programs. Another opinion states that there are no courses on criminology or psychology and what are the motives of fraud perpetrators in committing crimes in fraud and forensic accounting [21]. This research collects several important topics that must be taught in forensic accounting. Respondents were asked to give their opinions regarding 15 important topics in forensic accounting. The results are presented in Table 3, sorted by the highest to lowest mean values.

Table 3: Important Topics of Forensic Accounting

\begin{tabular}{llcc}
\hline No. & \multicolumn{1}{c}{ Topic } & Mean & $\begin{array}{c}\text { Standard } \\
\text { Deviation }\end{array}$ \\
\hline 1 & Fraud detection methods & 4,4681 & 0,6869 \\
2 & Fraud prevention and deterrence & 4,4043 & 0,7120 \\
3 & $\begin{array}{l}\text { Fraud investigation methods, } \\
\text { including the organization and }\end{array}$ & 4,3830 & 0,6774 \\
& $\begin{array}{l} \\
\text { evaluation of evidence }\end{array}$ & \\
4 & $\begin{array}{l}\text { Fraudulent financial statements and } \\
\text { analysis }\end{array}$ & 4,3830 & 0,6774 \\
5 & Corruption & 4,3191 & 0,7255 \\
6 & Asset misappropriation & 4,2979 & 0,7493 \\
7 & Digital forensics & 4,2553 & 0,8462 \\
8 & Auditing & 4,2128 & 0,7204
\end{tabular}




\begin{tabular}{llll}
\hline 9 & $\begin{array}{l}\text { Criminology, the legal environment, } \\
\text { and ethical issues }\end{array}$ & 4,2128 & 0,8581 \\
10 & $\begin{array}{l}\text { Forensic psychology, profiling, and } \\
\text { the fraud mindset }\end{array}$ & 4,2128 & 0,8059 \\
11 & $\begin{array}{l}\text { Interviewing and interrogations } \\
12\end{array}$ & 4,1915 & 0,7701 \\
& $\begin{array}{l}\text { Data analytic software (e.g., IDEA, } \\
\text { ACL, NVivo) }\end{array}$ & 4,1277 & 0,7107 \\
13 & Valuation of losses and damages & 4,1277 & 0,6794 \\
15 & Cyber-crime and security & 4,1064 & 0,8656 \\
\hline
\end{tabular}

Respondents stated that all of these are important topics in forensic accounting; this can be seen from the values of all the mean above 4 . The results of the five highest rankings indicate that fraud detection methods, fraud prevention, and fraud, investigation methods, including organization and evaluation of evidence, fraudulent financial statements and analysis, and corruption. Of the five highest topics chosen by respondents, all indicated that there was a connection with accounting. This result is closely related to the expertise respondents of this study as academicians in accounting. Respondents stated that:

"Forensic accounting is taught in Bachelor Accounting as a compulsory subject. The basis of introductory forensic courses at least introduces to students that cheating may be done even by someone we trust. It is important for accounting and auditing courses as a basis for understanding forensic accounting".

[5] research also shows that educators prefer topics related to accounting. The results of interviews with respondents also stated that accounting and auditing is a prerequisite skill for the student, which consistent with [17] indicating basic accounting, auditing knowledge, and skills that students should have when they are considering issues associated with fraud and forensic accounting. Furthermore, there is material about introductory forensic accounting that teaches the basics of fraud. Research $[7,16]$ also show that fundamental fraud is the most important topic chosen by academics to be taught in forensic accounting education.

As for topics such as interviewing and interrogation, data analysis software (e.g., IDEA, ACL, NVIVO), valuation of losses and damages, cyber-crime and security, and remediation, and conflict resolution have smaller mean values, as these topics require special knowledge in forensic accounting. This supports the previous result stating that the obstacle in accounting education is the lack of competence of lecturers. This particular expertise certainly requires a teacher who has expertise in this field, this could be a practitioner who has a lot of experience in this field. The respondent said: "must continue to be developed through collaboration with the professional association of Forensic Accountants, Forensic Accountant practitioners, law enforcement". Of course, the collaboration will make forensic accounting develop quickly, academics will know what kind of demand is needed in the field of forensic accounting. So that students will be equipped with expertise following what is expected. That way topics about forensic accounting that require special expertise can be taught by people who are competent in their fields. So the problem of obstacles regarding the limitations of teachers and the lack of qualified teachers will be overcome.

\subsection{Various Teaching Methods in Forensic Accounting}

In conducting the teaching-learning process it is certainly important regarding teaching techniques. Teachers must have teaching techniques that are adapted to the conditions of the students, which are more likely to succeed. Many teaching techniques will give different results from one technique to another. It could be that this technique will succeed at one time but at different conditions and times, it cannot work properly. In this research, respondents also gave their opinions regarding the importance of various teaching methods in forensic accounting. In this study, we provide twelve lists of teaching techniques taken from several previous studies. The results are presented in Table 4 , which is sorted from highest to lowest.

Table 4: Various Teaching Methods in Forensic Accounting

\begin{tabular}{|c|c|c|c|}
\hline No. & Methods & Mean & $\begin{array}{l}\text { Standard } \\
\text { Deviation }\end{array}$ \\
\hline 1 & Case Studies & 4.4894 & 0.6211 \\
\hline 2 & $\begin{array}{l}\text { Digital Data Recovery (e.g. Data } \\
\text { Recovery) }\end{array}$ & 4.2979 & 0.6226 \\
\hline 3 & Computer Forensics Lab & 4.2553 & 0.6746 \\
\hline 4 & Data Analytics Software (e.g. IDEA) & 4.2340 & 0.6982 \\
\hline 5 & Guest lecturers & 4.1702 & 0.7319 \\
\hline 6 & Role-playing & 4.1064 & 0.6989 \\
\hline 7 & Field trips & 4.0851 & 0.7754 \\
\hline 8 & Internships & 4.0851 & 0.8554 \\
\hline 9 & Moot Court activities & 4.0638 & 0.7634 \\
\hline 10 & Books & 4.0638 & 0.5674 \\
\hline 11 & $\begin{array}{l}\text { Student research project and } \\
\text { presentation }\end{array}$ & 4.0426 & 0.6580 \\
\hline 12 & Video & 4.0213 & 0.7068 \\
\hline
\end{tabular}

Based on the mean value shows that all methods of teaching forensic accounting are important. The results of the five highest techniques, according to academics are case studies, digital forensic software, computer forensic labs, data analysis software, and guest lectures. Respondent comments stated that:

\section{"In my opinion, the best method is a case study. With case studies, we can find out the fraudsters cheat. So students know more about various kinds of cheating models, maybe one type of crime, but the mode is different. It will be easier for students to accept because the incident happened".}

From the interviews, respondents also chose case studies as the most important technique. Respondents said that with a case study, students could understand the case that occurred and knowhow the perpetrator in committing fraud. Case studies help students with more fraud models and with various modus operandi on how to commit it.

Other respondents also stated that "this course should be taught with more practice so that students get a real experience". Forensic accounting will be better taught through practice so students can get an overview of this profession, what is done, and what is faced. However, there is one teaching technique that is also based on real-life experience but has a small mean value of 
moot court activities. Moot court activities require teachers who have an understanding of the law. As the previous findings that one of the obstacles in forensic accounting is the less qualified lecturer. This can be overcome by collaborating with practitioners in the field of law or also with law faculties to teach it. With this students can understand the conditions of the trial or when providing expert statements.

\section{Conclusion}

This study attempts to find out the perceptions of academicians regarding the development of current forensic accounting education. This study also reveals more deeply about forensic accounting education through interviews with respondents. The findings in this study indicate that forensic accounting services will continue to increase in the future. Opinions from the lecturer show that forensic accounting education should be offered as separate topic and given to bachelor and master students. Then the main obstacle in forensic accounting education is the lack of lecturers who are competent in this field. While important topics, according to academics are closely related to accounting and the best teaching method is a case study.

From these results, it can be used as a suggestion for consideration in compiling a forensic accounting curriculum. Many requests for forensic accounting services can be seen as an opportunity to offer forensic accounting courses in the accounting department to be able to provide various skills needed by students who want a career in forensic accounting. This study also shows the importance of experienced practitioners in the field of forensic accounting and universities to work together to overcome shortcomings in the lack of qualified lecturers. So that students obtain materials and techniques that are following current forensic accounting practices. The importance is also that there is a collaboration between accounting parties in collaboration with other faculties in teaching other material not controlled by accounting majors such as law, psychology, social behavior, and information technology.

These results also indicate that academicians are more concerned with teaching techniques based on actual practice or real events and the importance of expertise in computer forensics. There must be teaching methods that lead to real practice so that students will understand the activities or work of a forensic accountant. Understanding more deeply about a case and focusing on technological developments in forensic accounting today is an important thing as an additional experience for students. Besides that, with the presence of a guest lecturer, students can learn profiles and can also take valuable lessons from the experience of the speakers.

This study also has limitations. A low response rate of this study could be the result of this study containing bias so that it cannot be generalized, and most respondents are from accounting majors. Important topics for forensic accounting only come from limited sources, there may be other topics that have not been included in this list. The scope of coverage examines in this study can be widened. Future studies can include the technological developments and expertise of computer forensics. This would enhance the understanding of academics and policymakers. Furthermore, it can add respondents from other departments such as law, psychology, and sociology, and information technology, which is expected to obtain more comprehensive perspectives regarding forensic accounting education.

\section{Conflict of Interest}

The authors declare no conflict of interest.

\section{Acknowledgment}

We are grateful to the Lecturers of Accounting in Indonesia who are willing to become respondents and informants.

\section{References}

[1] T.D. Carpenter, "Audit Team Brainstorming, Fraud Risk Identification, and Fraud Risk Assessment: Implications of SAS No. 99 J.M. Tull School of Accounting Terry College of Business University of Georgia Audit Team Brainstorming, Fraud Risk Identification, and Fra," The Accounting Review, 82(5), 1119-1140, 2007.

[2] J.A. DiGabriele, "Implications of regulatory prescriptions and audit standards on the evolution of forensic accounting in the audit process," Journal of Applied Accounting Research, 10(2), 109-121, 2009, doi:10.1108/09675420910984673.

[3] M. Lal Bhasin, "An Empirical Investigation of the Relevant Skills of Forensic Accountants: Experience of a Developing Economy," European Journal Of Accounting Auditing and Finance Research, 1(June), 11-52, 2013. https://dx.doi.org/10.2139/ssrn.2676519

[4] G.S. Smith, "Computer Forensics: Helping to Achieve the Auditor's Fraud Mission?," Journal of Forensic Accounting, 6(1), 119-134, 2005.

[5] B. Kramer, M. Seda, G. Bobashev, "Current opinions on forensic accounting education," Accounting Research Journal, 30(3), 249-264, 2017. https://doi.org/10.1108/ARJ-06-2015-0082

[6] D.A. McMullen, M.H. Sanchez, "A Preliminary Investigation of the Necessary Skills, Education Requirements, and Training Requirements for Forensic Accountants," Journals of Forensic \& Investigative Accounting, 2(2), pp.30-48, 2010. doi:10.1108/09670910984673.

[7] Z. Rezaee, D.L. Crumbley, R.C. Elmore, "Forensic Accounting Education: A Survey of Academicians and Practitioners," Advances in Accounting Education Teaching and Curriculum Innovations, 6(May 2004), 193-231, 2004. https://papers.ssrn.com/sol3/papers.cfm?abstract_id=518263

[8] M. Seda, B. Kramer, "The Emergence of Forensic Accounting Programs in Higher Education,” Management Accounting Quarterly, 9(3), 15-24, 2008.

[9] M. Seda, B.K.P. Kramer, "An Examination of the Availability and Composition of Forensic Accounting Education in the United States and Other Countries," Journal of Forensic and Investigative Accounting, 6(1), 146, 2014.

[10] H.Y. Prabowo, "Better, faster, smarter: developing a blueprint for creating forensic accountants," Journal of Money Laundering Control, 16(4), 353378, 2013, doi:10.1108/JMLC-05-2013-0017.

[11] K.B. Peterson, A.B. Thomas, "Anti-Fraud Education In Academia," In Advances in Accounting Education Teaching and Curriculum Innovations, 21(18), 45-67, 2004. doi: 10.1016/S1085-4622(04)06003-1

[12] B.C. Melancon, "A New Accounting Culture," Journal of Accountancy, (October), 27-30, 2002.

[13] B.M.M. Houck, B. Morris, A. Richard, D. Riley, J. Robertson, J.T. Wells, "Forensic Accounting as an Investigative Tool Developing a Model Curriculum for Fraud and Forensic Accounting," The CPA Journal, 76(August), 68-71, 2006.

[14] G.S. Smith, D.L. Crumbley, "How Divergent Are Pedagogical Views Toward the Fraud/Forensic Accounting Curriculum?" Global Perspectives on Accounting Education, 6, 1-24, 2009.

[15] M. Kranacher, B.W. Morris, T. a. Pearson, R. a. Riley, "A Model Curriculum for Education in Fraud and Forensic Accounting," Issues in Accounting Education, 23(4), 505-519, 2008, doi:10.2308/iace.2008.23.4.505. 
[16] Z. Rezaee, E.J. Burton, "Forensic accounting education: insights from academicians and certified fraud examiner practitioners," Managerial Auditing Journal, 12(9), 479-489, 1997, doi:10.1108/02686909710185206.

[17] WVU, "Education and Training in Fraud and Forensic Accounting: A Guide for Educational Institutions, Stakeholder Organizations, Faculty, and Students," NCJRS Publication No.NIJ 21-71589, 1-70, 2007.

[18] R.D. Meservy, M. Romney, M.F. Zimbelman, "Certified Fraud Examiners: A Survey of Their Training, Experience and Curriculum Recommendations," Journal of Forensic Accounting, 7(January), 163-184, 2006.

[19] K.C. Carnes, N.J. Gierlasinski, "Forensic accounting skills: will supply finally catch up to demand?," Managerial Auditing Journal, 16(6), 378-382, 2001, doi:10.1108/02686900110395514.

[20] B. Apostolou, J.W. Hassell, R.M. James, W.F. Stephanie, "Accounting education literature review (2006-2009)," Journal of Accounting Education, 28(3-4), 145-197, 2010, doi:10.1016/j.jaccedu.2018.02.001.

[21] S. Ramamoorti, "The Psychology and Sociology of Fraud: Integrating the Behavioral Sciences Component Into Fraud and Forensic Accounting Curricula," Issues in Accounting Education, 23(4), 521-533, 2008, doi:10.2308/iace.2008.23.4.521.

[22] G.E. Curtis, "Legal and Regulatory Environments and Ethics: Essential Components of a Fraud and Forensic Accounting Curriculum," Issues in Accounting Education, 23(4), 535-543, 2008, doi:10.2308/iace.2008.23.4.535.

[23] T.A. Pearson, T.W. Singleton, "Fraud and Forensic Accounting in the Digital Environment," Issues in Accounting Education, 23(4), 545-559, 2008.

[24] L.E. Heitger, D.L. Heitger, "Incorporating Forensic Accounting and Litigation Advisory Services Into The Classroom," Issues in Accounting Education, 23(4), 561-572, 2008.

[25] H.H. Meier, R.R. Kamath, Y. He, "Courses on Forensics and Fraud Examination in the Accounting Curriculum," Journal of Leadership, Accountability, and Ethics, 8(1), 1-8, 2010. doi: 10.1016/S1085-462060031

[26] S. Hegazy, A. Sangster, A. Kotb, Mapping forensic accounting in the UK, Elsevier Inc., 2017, doi:10.1016/j.intaccaudtax.2016.12.004.

[27] J.W. Creswell, Research design: qualitative, quantitative, and mixed methods approaches fourth, SAGE Publications, Inc, United States of America Library, 2014. 